\title{
NMR Analysis of the Effect of Validoxylamine A, a Trehalase Inhibitor, on the Larvae of the Cabbage Armyworm
}

\author{
Yoshiaki Kono, Satoshi Takeda,* Yukihiko Kameda,** \\ Masakazu Takahashi, Kazuhiro Matsushita,*** \\ Masami Nishina*** and Eitaro HoRI*** \\ Department of Medical Entomology, The National Institute of Health, \\ Shinjuku-ku, Tokyo 162, Japan \\ *National Institute of Sericultural and Entomological Science, Owashi, Tsukuba 305, Japan \\ **School of Pharmacy, Hokuriku University, Kanagawa-machi, Kanazawa 920-11, Japan \\ ***Department of Medical Zoology, Saitama Medical School, \\ Moroyama, Iruma-gun, Saitama 305-04, Japan
}

(Received September 5, 1994; Accepted November 5, 1994)

\begin{abstract}
Injection of trehalase inhibitor, validoxylamine A (VAA, $10 \mu \mathrm{g} /$ insect) evoked relaxation of segmental muscle and decrease of the pulsation of dorsal vessel in the final instar larvae of Mamestra brassicae. Ninety percent of the trehalase activity of the midgut was inhibited in a day. The larvae died afterward of incomplete pupation. We analysed the haemolymph components after the injection by ${ }^{1} \mathrm{H}$ NMR and ${ }^{13} \mathrm{C}$ NMR to elucidate the cause of the abnormality. Trehalose was actively synthesized from glucose regardless of VAA treatment and utilization of trehalose was suppressed by VAA. Trehalose concentration rose to 1.7 and 2.0 times of the control 1 and 3 days after injection respectively, and to 3.3 times at prepupal stage. Amino acid concentrations decreased once at the middle of the instar, but became at higher level than the control at prepupal stage. At this stage, phosphorylcholine level fell with increase of choline, and $N$-acetylglucosamine appeared. Accumulation of the components seemed to be caused by inhibition of the utilization of materials for pupal formation.
\end{abstract}

\section{INTRODUCTION}

Trehalose is a common blood sugar in insects, and is utilized as an energy source in their tissues. Hydrolyzing enzyme of the sugar, trehalase, is one of the most important enzyme in energy metabolisms and distributed in every tissue and organ of the insect. ${ }^{1-3)}$ It has often been pointed out that the inhibitors of trehalase are prospective candidates for selective and safer insecticides because mammals have no metabolic pathway for trehalose. ${ }^{4,5)}$ There have been several reports on insecticidal activity of trehalase inhibitors. However, their substrate specificity was not so high. ${ }^{6-8)}$ Validoxylamine A (VAA, Fig. 1) an amino sugar, whose glucoside, validamycin A, has been used as a fungicide against the rice sheath blight for a long time, was proved to be a potent and specific inhibitor of trehalase. ${ }^{9)}$ VAA inhibits trehalases from various organisms competitively because of resemblance of its chemical structure to that of trehalose, and it shows no inhibitory activity to other kinds of sugar hydrolyzing enzymes: amylase, glucosidases, etc. ${ }^{10)}$ Recently, insecticidal activity was shown in lepidopterous insect larvae; Spodoptera litura, ${ }^{11,12)}$ Bombyx mori $^{13)}$ and Mamestra brassicae. ${ }^{12)}$ Other kinds of physiological alterations were also evoked 


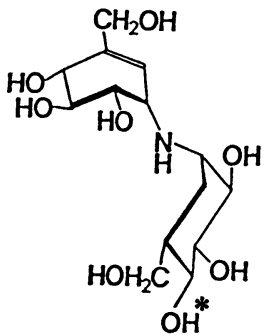

Validoxylamine A

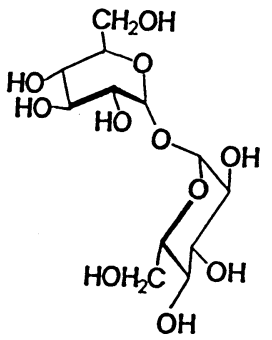

$\alpha, \alpha$-Trehalose
Fig. 1 Structures of validoxylamine $\mathrm{A}$ and $\alpha, \alpha-$ trehalose.

Validamycin A is a monoglycoside at $\mathrm{H}^{*}$ in the structure of validoxylamine $\mathrm{A}$.

by the administration of VAA. Injection of VAA to the pupae of $B$. mor $i$ induced a change of egg diapause determination from diapause egg producers to non-diapause egg producers, ${ }^{14)}$ and prevented glutinous material production in colleterial glands as a result of trehalase inhibition. ${ }^{15,16)}$ In Periplaneta americana, flight activity was suppressed by VAA injection. ${ }^{17)}$ In the present paper, effect of VAA on the sugar metabolism was analyzed using NMR technique in $M$. brassicae larvae to elucidate the cause of the lethal activity of VAA to this insect.

\section{MATERIALS AND METHODS}

\section{Chemicals}

VAA was purified according to the previous paper. ${ }^{18)} \quad\left[1-{ }^{18} \mathrm{C}\right]$ Glucose $(99$ atom \%) and $\mathrm{D}_{2} \mathrm{O}$ were purchased from Cambridge Isotope Laboratories (England) and CEN Sacley (France), respectively.

$\alpha, \alpha-\left[1,1^{\prime}-{ }^{13} \mathrm{C}\right]$ Trehalose was synthesized biologically by phytopathogenic fungus, Rhyzoctonia solani, from $\left[1-{ }^{13} \mathrm{C}\right]$ glucose in the previous study. ${ }^{19)}$ Other chemicals used were of analytical grade.

\section{Insects}

The stock culture of the cabbage armyworm, $M$. brassicae, was maintained on artificial diets under long-day conditions $\left(20^{\circ} \mathrm{C}, \mathrm{LD} 16: 8\right)$. The larvae were collected 1 day after the final larval molt from the stock culture and subjected to the experiments.

\section{Treatment of $V A A$}

The larvae were anesthetized by immersing in water, and two microliters of aqueous solution containing $10 \mu \mathrm{g}$ VAA was injected into the dorsal body cavity of the larvae with a microsyringe. The treated larvae were fed with the artificial diet in plastic containers at $20^{\circ} \mathrm{C}$, LD 16:8 and their symptoms were observed. The same volume of water as above was injected to the control larvae.

\section{Observation of VAA Effect on the Larvae}

One day after injection of VAA, relaxation of the segmental muscles was observed by touching the larval body with fingers and trequency of pulsation of the dorsal vessel was counted for one minute under a microscope. Then, their subsequent developmental abnormalities were checked by the same method of previous paper. ${ }^{12)}$

\section{Measurement of Trehalase Activity}

Midgut was dissected out in ice water and contents in the lumen were discarded with the peritrophic membrane. Three midguts were homogenized with $3 \mathrm{ml}$ phosphate buffer solution $(\mathrm{pH} 7.2$ ) and centrifuged at $2000 \times g$, for 30 min. One tenth milliliter of the homogenate supernatant mixed with $0.2 \mathrm{ml}$ of 60 $\mathrm{mm}$ trehalose (substrate) was incubated at $30^{\circ} \mathrm{C}$ for $10 \mathrm{~min}$ and bathed in boiling water for 5 min to stop the trehalase reaction. The reaction mixture was diluted with $0.5 \mathrm{ml}$ distilled water and again centrifuged at $2000 \times g$ for 10 $\min$.

A $0.2 \mathrm{ml}$ sample of the supernatant was incubated with $1 \mathrm{ml}$ of glucose assay mixture including glucose oxidase, peroxidase, 4-aminoantipyrine and phenol (Glucose B-test Wako, Wako Chem. Indus.) at $30^{\circ} \mathrm{C}$ for $20 \mathrm{~min}$. The glucose concentration in the mixture was determined by the increase in absorbance at 505 $\mathrm{nm}$ during the trehalase reaction.

\section{NMR Analysis}

The haemolymph bled from one of the third abdominal legs cut was collected (150-300 $\mu \mathrm{l}$ from 10 larvae), and centrifuged with a small amount of phenylthiourea at $2000 \times g$ for $10 \mathrm{~min}$ at $4^{\circ} \mathrm{C}$. The supernatant was diluted $2-4$ times with heavy water as NMR sample. As 
for whole body homogenate, the larvae whose haemolymph had been sampled were homogenized with $\mathrm{D}_{2} \mathrm{O}$ (10 larvae $\left./ 1.5 \mathrm{ml}\right)$ in ice water and centrifuged at $2000 \times g$ for $20 \mathrm{~min}$ at $4^{\circ} \mathrm{C}$. The supernatant was again centrifuged at $10,000 \times g$ for $30 \mathrm{~min}$ at $4^{\circ} \mathrm{C}$, and its supernatant was subjected to the NMR sample. The samples were stored at $-20^{\circ} \mathrm{C}$ until the NMR analysis.

In order to observe the effect of VAA on the sugar metabolism, $200 \mu \mathrm{g} /$ insect $\left[1-{ }^{18} \mathrm{C}\right]$ glucose (1 mg/insect in vivo experiment) or $\left[1,1^{\prime}-{ }^{13} \mathrm{C}\right]$ trehalose in $4 \mu \mathrm{l}$ water was injected to the larvae with or without $2 \mathrm{hr}$ preceeding injection of $10 \mu \mathrm{g} /$ insect VAA.

The samples $(450 \mu \mathrm{l})$ ad-lib with $50 \mu \mathrm{l}$ of 10 mm 3-trimethylsilyl 2,2,3,3-tetradeutropropionate (TSP) or $100 \mathrm{~mm}$ dioxane in $\mathrm{D}_{2} \mathrm{O}$ were subjected to ${ }^{1} \mathrm{H}$ NMR $(400 \mathrm{MHz})$ or ${ }^{13} \mathrm{C} \mathrm{NMR}$ $(100 \mathrm{MHz})$ analysis as an inner standard, respectively, with a JEOL JNM-EX400 FTNMR spectrometer.

Assignment of the signals of the chemicals on NMR spectra was made by adding supposed organic chemicals to the sample, and by checking the overlapping of the signals. The concentration of haemolymph components could be estimated roughly by comparing the signal strengths in NMR analysis to those of corresponding compound of known concentration (Table 1). In ${ }^{13} \mathrm{C}$ NMR analysis, the labeled trehalose concentration could be calculated by the difference between its $[1-\mathrm{C}]$ and [2-C] signal strengths, taking account of the natural abundance of ${ }^{13} \mathrm{C}$ as $1 \%$ and the trehalose concentration estimated in ${ }^{1} \mathrm{H}$ NMR analysis of the same sample.

\section{RESULTS}

\section{Symptoms Induced by VAA Injection}

In $3 \mathrm{hr}$ after the injection of VAA $(10 \mu \mathrm{g} /$ insect) to the 2nd day last instar larvae, their segmental muscle became to relax and the symptom sustained for 1-2 days. When the pulsation frequency of the dorsal vessel was counted 1 day after the injection, the frequency was $49.1 \pm 9.6 / \mathrm{min}(n=18)$ which was significantly less than that of the control

Table 1 Concentration of haemolymph components and the effect of VAA in Mamestra larvae.

\begin{tabular}{|c|c|c|c|c|c|c|c|}
\hline \multirow{3}{*}{ Chemical } & \multirow{3}{*}{$\begin{array}{c}\text { Chemical } \\
\left.\text { shift }^{a}\right) \\
(p p m)\end{array}$} & \multirow{3}{*}{$\begin{array}{l}\text { Peak } \\
\text { height } \\
\left.\text { ratio }^{b}\right)\end{array}$} & \multicolumn{5}{|c|}{ Concentration in $\mathrm{mm}$} \\
\hline & & & \multicolumn{2}{|c|}{ 3rd day larva } & \multirow{2}{*}{$\begin{array}{c}\begin{array}{c}5 \text { th day } \\
\text { larva }\end{array} \\
+ \text { VAA }\end{array}$} & \multicolumn{2}{|c|}{ Prepupa } \\
\hline & & & -VAA & $+\mathrm{VAA}$ & & $-\mathrm{VAA}$ & $+\mathrm{VAA}$ \\
\hline TSP & $0.000 \mathrm{~s}$ & 1.00 & & & & & \\
\hline Leucine & $1.004 \mathrm{t}$ & 0.15 & 1.3 & 1.2 & 0.7 & 2.6 & 6.3 \\
\hline Isoleucine & $1.022 \mathrm{t}$ & 0.22 & 1.7 & 1.5 & 0.7 & 4.2 & 6.8 \\
\hline Valine & $1.054 \mathrm{~d}$ & 0.12 & 2.2 & 2.0 & 0.8 & 5.5 & 8.6 \\
\hline Lactate & $1.327 \mathrm{~d}$ & 0.08 & 2.8 & 4.8 & 2.3 & 5.0 & 9.4 \\
\hline$\alpha$-Alanine & $1.473 \mathrm{~d}$ & 0.13 & 2.9 & 2.3 & 1.2 & 4.1 & 8.7 \\
\hline \multicolumn{8}{|l|}{$N$-Acetyl } \\
\hline glucosamine & $2.058 \mathrm{~s}$ & 0.29 & - & - & - & - & 15.5 \\
\hline Pyruvate & $2.377 \mathrm{~s}$ & 0.20 & - & - & - & 1.0 & 4.7 \\
\hline Succinate & $2.413 \mathrm{~s}$ & 0.43 & 1.9 & 2.4 & 1.8 & 6.5 & 5.2 \\
\hline Citrate & $2.552 \mathrm{q}$ & 0.09 & 10.1 & 12.5 & 8.0 & 20.6 & - \\
\hline Choline & $3.204 \mathrm{~s}$ & 0.80 & - & - & 1.0 & - & 4.9 \\
\hline \multicolumn{8}{|l|}{ Phosphoryl } \\
\hline choline & $3.223 \mathrm{~s}$ & 0.54 & 22.5 & 28.1 & 18.9 & 23.8 & 17.0 \\
\hline Trehalose & $3.459 \mathrm{t}$ & 0.09 & 21.6 & 35.8 & 43.2 & 33.8 & 110.4 \\
\hline Glycine & $3.565 \mathrm{~s}$ & 0.17 & 8.8 & 11.4 & 11.8 & 17.9 & 15.4 \\
\hline
\end{tabular}

a) ${ }^{1} \mathrm{H}$ NMR Chemical shift of the peak measured. $s$ : singlet, $d$ : doublet, $t$ : triplet, q: quartet.

b) Ratio of peak height of $1 \mathrm{~mm}$ chemical to that of $1 \mathrm{~mm}$ TSP.

VAA (10 $\mu \mathrm{g} /$ larva) was injected to the 2 nd day final instar larvae. 
larvae $(60.4 \pm 5.7 / \mathrm{min})$. The injected larvae deposited wet and sticky faeces and some of them were attached together. The lethal effect of VAA injection appeared at the late stage of the larva. Eighty percent of 15 larvae became larval-pupal intermediate (pupal cuticle was formed under the larval cuticle, but was not shed), $13 \%$ of the larvae shed partially larval cuticle, and the remaining one larva pupated with the marginal part of wing pad separated from body cuticle. All of the treated individuals with abnormality died afterward.

\section{Inhibition of the Trehalase Activity}

Trehalase activity of midgut of the control larvae was determined to be $2.8 \mu \mathrm{mol} /$ midgut/ $20 \mathrm{~min}$ as produced glucose. The activity of the midgut of VAA treated larvae reduced to only $10 \%$ of the control (average of 2 replications) in a day.

\section{Components of Larval Haemolymph}

On ${ }^{1} \mathrm{H}$ NMR spectrum of the haemolymph of the 3rd day last instar larvae (Fig. 2(a)), 10 chemicals were assigned: leucine (L), isoleucine $(\mathrm{iL})$, valine $(\mathrm{V})$, lactate $(\mathrm{La})$, alanine

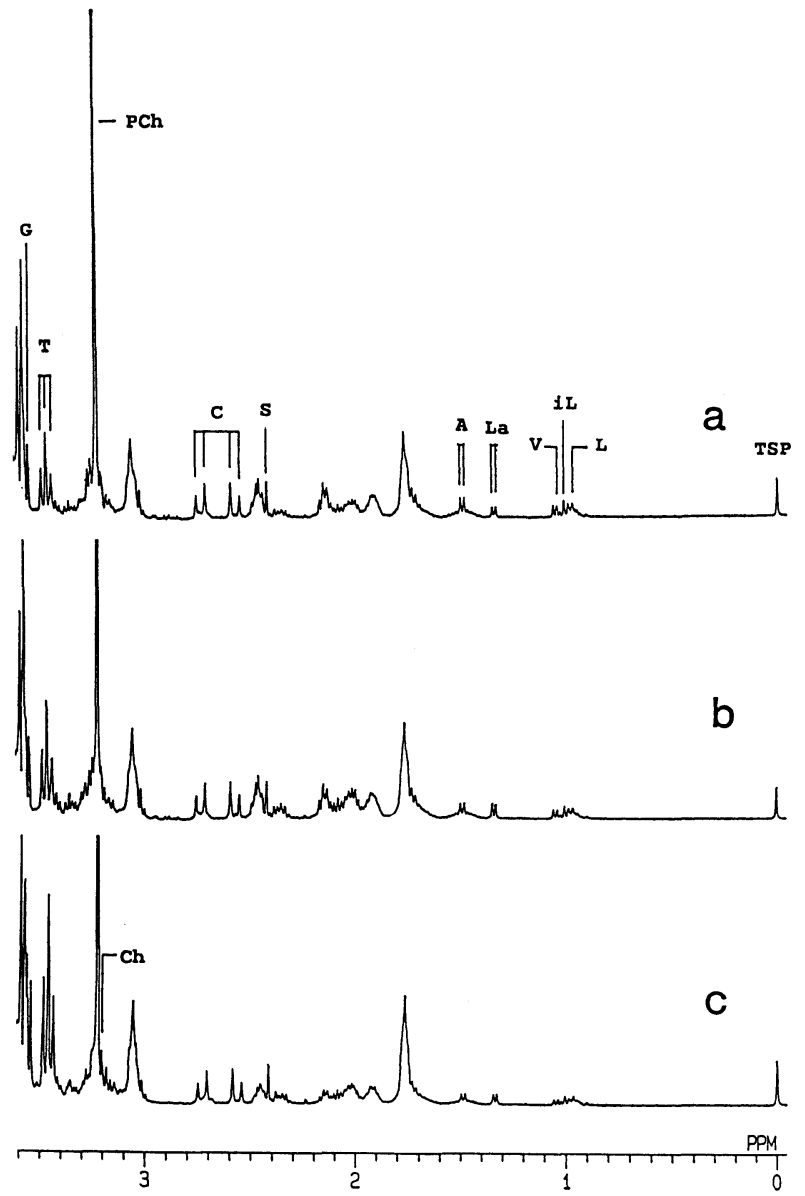

Fig. $2{ }^{1} \mathrm{H}$ NMR spectra of the haemolymph of the final instar larvae of Mamestra brassicae. (a) Third day larvae which were injected with $200 \mu \mathrm{g} /$ larva $\left[1-{ }^{13} \mathrm{C}\right] \mathrm{glucose}$ at the 2 nd day but without VAA injection. (b) Third day larvae which were injected with both VAA and [1${ }^{13} \mathrm{C}$ ]glucose at the 2 nd day. (c) Fifth day larvae which were injected with VAA at the 2 nd day and with $\left[1-{ }^{13} \mathrm{C}\right]$ glucose at the 4th day. TSP: 3-trimethylsilyl 2,2,3,3-tetradeutropropionate as an inner standard, A: alanine, C: citrate, G: glycine, iL: isoleucine, L: leucine, La: lactate, PCh: phosphorylcholine, $\mathrm{S}$ : succinate, $\mathrm{T}$ : trehalose, $\mathrm{V}$ : valine. 
(A), succinate $(\mathrm{S})$, citrate $(\mathrm{C})$, phosphorylcholine $(\mathrm{PCh})$, trehalose $(\mathrm{T})$, glycine $(\mathrm{G})$. Four other chemicals: acetate (Ac), $N$-acetylglucosamine $(\mathrm{NAG})$, pyruvate $(\mathrm{P})$ and choline $(\mathrm{Ch})$, were detected at later stages or in VAA treated individuals. Peak area or peak height indicates the relative amount of the chemicals. Then, their concentrations were determined by comparing the signal strength to that of standard chemicals of known concentration (Table 1). Citrate, phosphorylcholine and glycine were contented at high concentration as trehalose.

\section{Effect of VAA on Haemolymph Components}

\subsection{Three hours after injection}

${ }^{1} \mathrm{H}$ NMR spectra (not shown) and ${ }^{13} \mathrm{C}$ NMR spectra (Fig. 3) of the haemolymph of the larvae which were injected with $200 \mu \mathrm{g} /$ insect $\left\lceil 1-{ }^{13} \mathrm{C}\right]$ glucose with and without $2 \mathrm{hr}$ prior injection of VAA. There appeared no difference in the compositions between treated (Fig. 3(b))

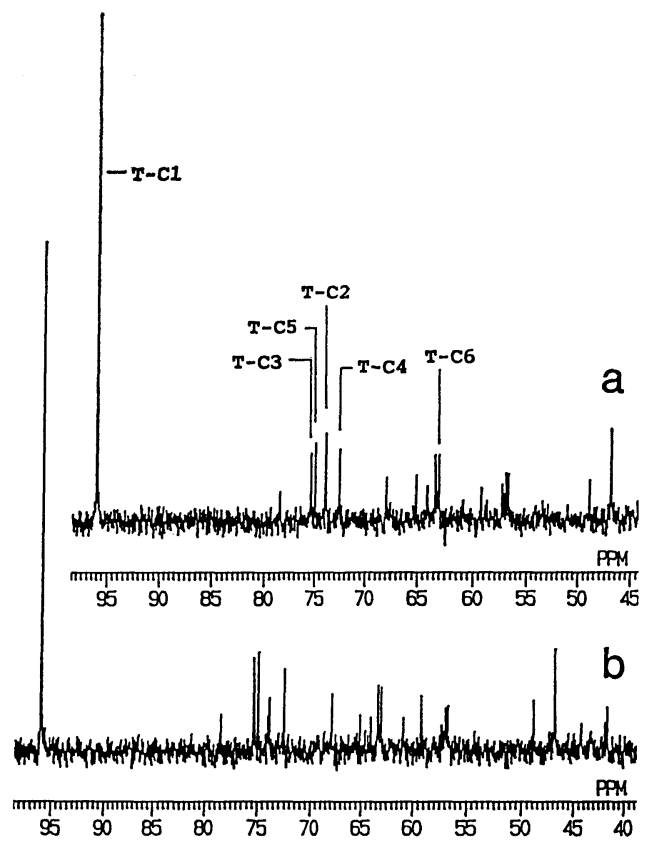

Fig. $3{ }^{13} \mathrm{C}$ NMR spectra of the haemolymph of the 2nd day final instar larvae of Mamestra brassicae $3 \mathrm{hr}$ after injection of $200 \mu \mathrm{g} /$ larva $\left[1^{-13} \mathrm{C}\right]$ glucose, without (a) and with (b) $2 \mathrm{hr}$ previous injection of $10 \mu \mathrm{g} /$ larva VAA.

T-C1-T-C6: signals of [1-C]-[6-C] in trehalose. and control (Fig. 3(a)) larval haemolymph. It was indicated that all injected $\left[1-{ }^{13} \mathrm{C}\right]$ glucose metabolized in $3 \mathrm{hr}$, because the signals of $[1-\mathrm{C}]$ in glucose at 95.0 and $98.8 \mathrm{ppm}$ disappeared. At the same time, drastic increase of $\left[1,1^{\prime}-\mathrm{C}\right]$ signal of trehalose at $96.2 \mathrm{ppm}$ showed active synthesis of trehalose from glucose regardless of VAA injection. Trehalose concentrations of control and treated larvae were calculated from ${ }^{1} \mathrm{H}$ NMR to be 19.6 and $20.4 \mathrm{~mm}$, respectively, from ${ }^{1} \mathrm{H}$ NMR spectra. The concentration of the labeled trehalose was determined to be about $0.29 \mathrm{~mm}$, according to the calculation procedure mentioned in MATERIALS AND METHODS.

In vivo measurement of sugars in the larva also supported the rapid production of trehalose from glucose (Fig. 4). A small portion of $\left[1-{ }^{13} \mathrm{C}\right]$ glucose injected was remained $1 \mathrm{hr}$ after the injection (Fig. 4(b)) and no labeled glucose remained $3 \mathrm{hr}$ after the injection (Fig. $4(\mathrm{c}))$. On the contrary, $\left[1,1^{\prime}-{ }^{13} \mathrm{C}\right]$ trehalose increased in $1 \mathrm{hr}$ and glycogen (105.2 ppm) increased slightly in $3 \mathrm{hr}$.

\subsection{One day after injection}

One day after the injection of VAA, only

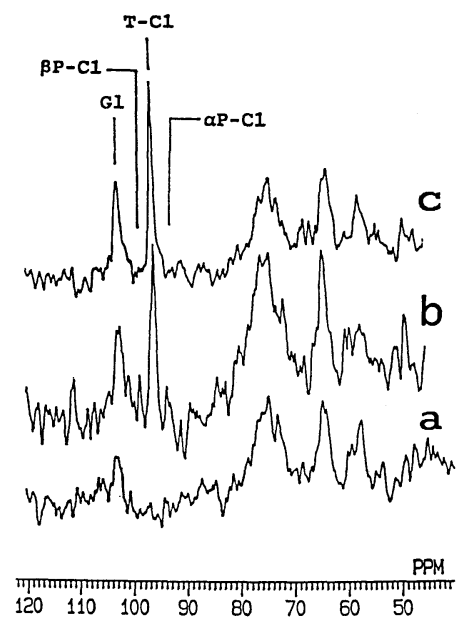

Fig. 4 In vivo ${ }^{13} \mathrm{C}$ NMR spectrometry of the 2nd day final instar larvae of Mamestra brassicae.

(a) No treatment. (b) One hour after injection of $1 \mathrm{mg} /$ larva $\left[1-{ }^{13} \mathrm{C}\right]$ glucose. (c) Three hours after injection. G1: signal of glycogen, $\alpha \mathrm{P}-\mathrm{Cl}$ and $\beta \mathrm{P}-\mathrm{Cl}$ : signals of [1-C] in glucose of $\alpha$ - and $\beta$-pyranose structure. 
trehalose concentration rose in the haemolymph components, from $21.6 \mathrm{~mm}$ (control, Fig. 2(a)) to $35.8 \mathrm{~mm}$ (Fig. 2(b)) in ${ }^{1} \mathrm{H}$ NMR analysis. ${ }^{18} \mathrm{C}$ NMR analysis of the haemolymph injected with $\left[1-{ }^{13} \mathrm{C}\right]$ glucose indicated

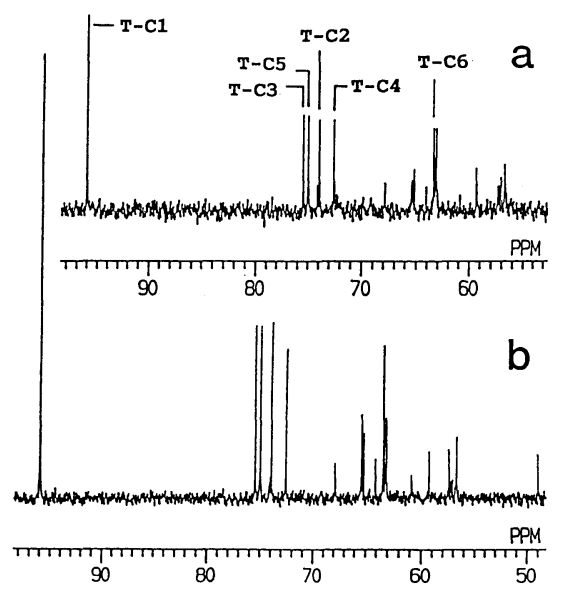

Fig. $5{ }^{13} \mathrm{C}$ NMR spectra of the haemolymph of the 3rd day final instar larvae of Mamestra brassicae injected with $200 \mu \mathrm{g} /$ larva $\left[1-{ }^{13} \mathrm{C}\right]$ glucose.

(a) Without previous injection of VAA. (b) With previous injection of VAA. Abbreviations are the same as Fig. 3.

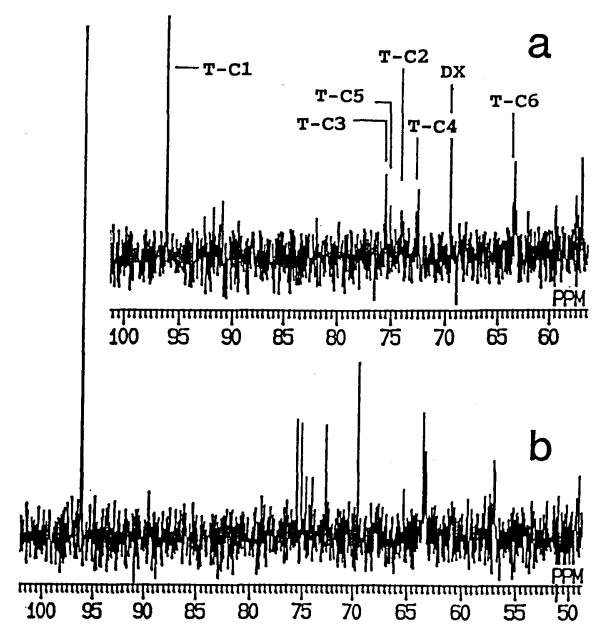

Fig. $6{ }^{13} \mathrm{C}$ NMR spectra of the haemolymph of the 3rd day final instar larvae of Mamestra brassicae injected with $200 \mu \mathrm{g} /$ larva $\left[1,1^{\prime}-13 \mathrm{C}\right]$ trehalose.

(a) Without previous injection of VAA. (b) With previous injection of VAA. Abbreviations are the same as Fig. 3. that the concentration of labeled trehalose at $\left[1,1^{\prime}-\mathrm{C}\right]$ increased to $0.58 \mathrm{~mm}$ in VAA treated larvae (Fig. 5(b)), while that of control larvae remained to be $0.25 \mathrm{~mm}$. When labeled trehalose $(200 \mu \mathrm{g} /$ insect) was injected instead of glucose, the labeled trehalose accumulated in the haemolymph at $1.35 \mathrm{~mm}$ by VAA injection (Fig. 6). This level of labeled trehalose was more than twice of the concentration of control larvae, $0.60 \mathrm{~mm}$.

\subsection{Three days after injection}

In 3 days after the VAA injection, the trehalose concentration increased to twice ( 43.2 $\mathrm{mm})$ of that in the control larvae $(21.6 \mathrm{~mm})$, and concentration of amino acids: leucine, valine, and alanine decreased in the haemolymph (Table 1). Choline increased to be detectable in 3 days. Within one day between 2 days and 3 days after VAA injection, $0.84 \mathrm{~mm}\left[1,1^{1}-{ }^{13} \mathrm{C}\right]$ trehalose synthesized from $\left[1-{ }^{13} \mathrm{C}\right]$ glucose was accumulated in the haemolymph of treated larvae, while $0.35 \mathrm{~mm}$ labeled trehalose remained in the haemolymph of control larvae.

\subsection{Prepupal stage}

At prepupal stage when apparent morphological abnormality was induced by VAA, the haemolymph components also changed remarkably (Fig. 7, Table 1). Trehalose concentration of treated larvae was evaluated to be 3.3 times $(110.4 \mathrm{~mm}$ ) of the control level $(33.8 \mathrm{~mm})$. Concentration of phosphorylcholine decreased and that of choline, to the contrary, increased. Concentrations of amino acids such as leucine, isoleucine, valine and alanine, and organic acids such as lactate and pyruvate increased, while those of succinate and citrate decreased, compared with control larvae. $\quad N$-Acetylglucosamine $(15.5 \mathrm{~mm})$ was appeared (Table 1) and acetate was detected (Fig. 7) in the treated individuals.

\section{Effect of VAA on Tissues}

Whole body homogenate was analyzed with ${ }^{1} \mathrm{H}$ NMR and compared between VAA treated and non-treated larvae 1 day after the treatment. In the homogenate of VAA treated larvae, high level of labeled trehalose was detected (Fig. 8(c)). Even when $\left[1,1^{\prime}-{ }^{13} \mathrm{C}\right]$ trehalose (Fig. 8(a)) or $\left[1-^{13} \mathrm{C}\right]$ glucose (Fig. 8(b)) was injected to the larvae without VAA in- 

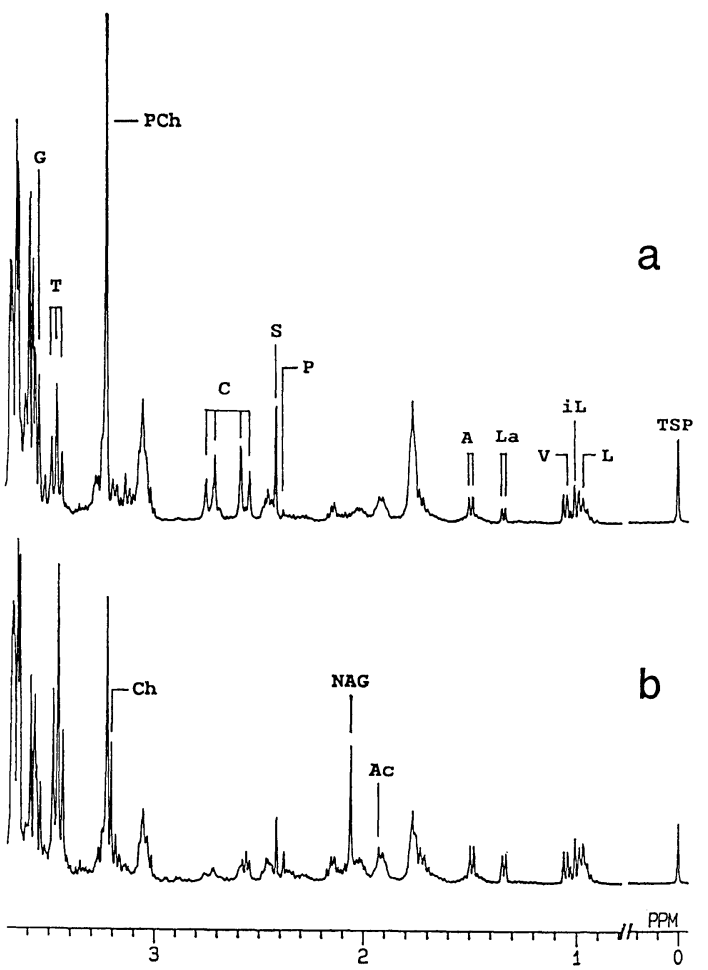

Fig. $7{ }^{1} \mathrm{H}$ NMR spectra of the haemolymph of prepupae of Mamestra brassicae.

(a) No treatment. (b) With VAA injection at the 2nd day of final instar. Ch: choline, NAG: $N$ acetylglucosamine, $\mathrm{P}$ : pyruvate, other abbreviations are the same as Fig. 2.

jection, little amount of trehalose and no glucose were found in the homogenate.

\section{DISCUSSION}

NMR spectrometric method is a very powerful tool to analyze both quantitative and qualitative changes of major components of low molecular weight in organisms. The method has already been adopted to the studies of nutrient metabolism in insects. ${ }^{20-26)}$ In the present study, the method was used to elucidate the influence of a trehalase inhibitor on the sugar metabolism in $M$. brassicae larvae.

VAA has a strong inhibitory activity against trehalases from various organisms including insects, ${ }^{9}{ }^{27)}$ but its activity is very specific to trehalase without showing any inhibitory activity against other kinds of saccharases. ${ }^{10)}$ It

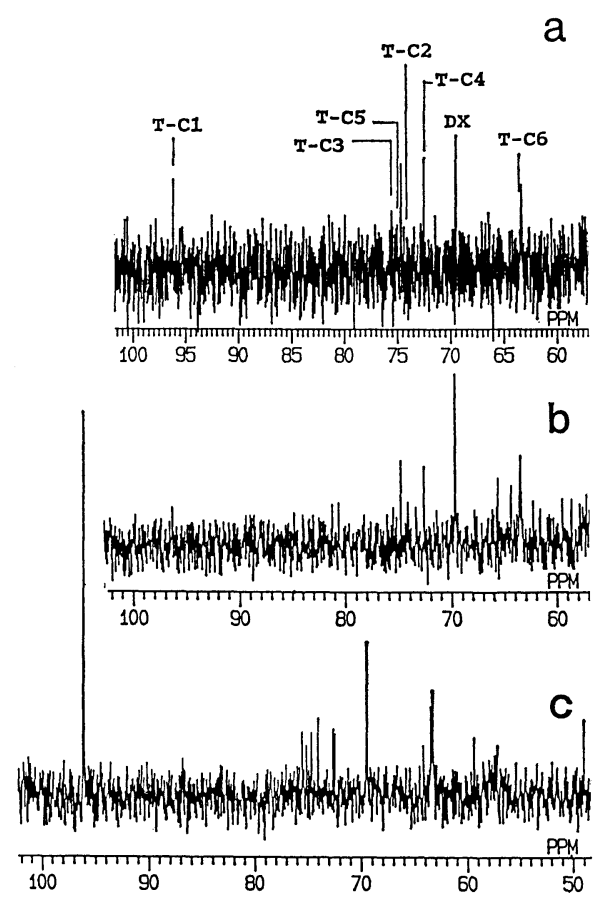

Fig. $8{ }^{13} \mathrm{C}$ NMR spectra of the body homogenate supernatant of the 3rd day final instar Mamestra brassicae larvae.

(a) One day previous injection with $\left[1,1^{\prime}-{ }^{13} \mathrm{C}\right]$ trehalose. (b) One day previous injection with $\left[1^{-13} \mathrm{C}\right]$ glucose. (c) One day previous injection with both VAA and $\left[1-{ }^{13} \mathrm{C}\right]$ glucose. Dx: dioxane, other abbreviations are the same as Fig. 3.

has been studied that in vivo injection of VAA strongly inhibited trehalase activity in ovaries $^{14)}$ and in arborescent regions of colleterial glands ${ }^{16)}$ of $B$. mori, and in flight muscle of $P$. americana ${ }^{17)}$ as the present result that $90 \%$ of the activity was inhibited in Mamestra midgut. Therefore, the primary effect of VAA was supposed to be inhibition of the trehalase in the treated larvae of $M$. brassicae. On the other hand, the experiments using labeled glucose indicated that the trehalose synthesis from glucose was not affected by VAA. Then, trehalose was accumulated by VAA treatment in both tissues and haemolymph without changes of other components in a day. The same elevation of trehalose concentration in the haemolymph was observed in $B$. mori, ${ }^{13)} P$. americana ${ }^{17)}$ and several species of flies (unpublished data) 
treated with VAA.

The disturbance of utilization of trehalose, an energy source, in muscle by VAA seemed to evoke the decrease of pulsation of the dorsal vessel and the relaxation of segmental muscles.

By VAA treatment, amino acid concentrations in the haemolymph decreased in the mid stage of the last instar, though amino acids and organic acids except for succinate and citrate increased in prepupal stage (Table 1). The difference seemed to reflect different physiological conditions of two stages; the normal level of nutritional compounds was not maintained in the haemolymph by the disturbance of energy metabolism in the mid stage, while in prepupal stage, a large amount of nutrients released into the haemolymph for pupal metamorphosis were not consumed normally in most tissues by the disturbance of energy metabolism and remained in the haemolymph. Appearance of $N$-acetyl-glucosamine, a precursor of cuticle structure, only in the treated prepupae haemolymph (Fig. 7) obviously indicated that the cuticle formation did not occur normally by VAA administration. Lethal effect of VAA appeared at the pupation regardless of ages of the VAA injection in the final instar (Kono, unpublished data). In conclusion, VAA disturbed energy metabolism in every stage of the growth, but its lethal effect appears only at the pupation because abnormality in reconstruction of tissues and organs at the metamorphosis are mortal.

\section{ACKNOWLEDGMENTS}

The study was partly supported by a Grant-in-Aid for General Science Research (No. 03454057) from the Ministry of Education, Science and Culture, Japan.

\section{REFERENCES}

1) G. R. Wyatt: Adv. Insect Physiol. 4, 287 (1967)

2) M. Sumida \& O. Yamashita: J. Comp. Physiol. 115, 241 (1977)

3) T. Yaginuma \& G. M. Happ: J. Comp. Physiol. $B$ 157, 765 (1988)

4) S. V. Evans, L. E. Fellows \& E. A. Bell: Phytochemistry 22, 768 (1983)

5) L. E. Fellows: Pestic. Sci. 17, 602 (1986)

6) B. C. Campbell, K. J. Molyneux \& K. C. Jones: J. Chem. Ecol. 13, 1795 (1987)

7) S. Murao \& S. Miyata: Agric. Biol. Chem. 44,
$219(1980)$

8) K. Nishimura, K. Mori, Y. Yoshikuni \& F, Fujita: J. Pesticide Sci. 15, 237 (1990)

9) Y. Kameda, N. Asano, T. Yamaguchi \& K. Matsui: J. Antibiotics 40, 563 (1987)

10) N. Asano, T. Yamaguchi, Y. Kameda \& K. Matsui: J. Antibiotics 40, 526 (1987)

11) N. Asano, M. Takeuchi, Y. Kameda, K. Matsui \& Y. Kono: J. Antibiotics 43, 722 (1990)

12) Y. Kono, S. Takeda \& Y. Kameda: J. Pesticide Sci. 19, 39 (1994)

13) Y. Kono, S. Takeda, Y. Kameda, M. Takahashi, K. Matsushita, M. Nishina \& E. Hori: Appl. Entomol. Zool. 28, 379 (1993)

14) S. Takeda, Y. Kono \& Y. Kameda: Ent. Exp. Appl. 46, 291 (1988)

15) S. Takeda, Y. Kono \& Y. Kameda: J. Seric. Sci. Jpn. 55, 238 (1990)

16) X. Yao, H. Fugo \& S. Takeda: J. Seric. Sci. Jpn. 60, 296 (1991)

17) Y. Kono, M. Takahashi, K. Matsushita, M. Nishina, Y. Kameda \& E. Hori: J. Insect Physiol. 40, 455 (1994)

18) Y. Kameda, N. Asano, T. Yamaguchi, K. Matsui, S. Horii \& H. Fukase: J. Antibiotics 39, 1491 (1986)

19) N. Asano, K. Matsui, S. Takeda \& Y. Kono: Carbohydr. Res. 243, 71 (1993)

20) T. Asakura, H. Suzuki \& Y. Watanabe: $J$. Seric. Sci. Jpn. 54, 504 (1985)

21) T. Asakura, Y. Kawaguchi, M. Demura \& M. Osanai: Insect Biochem. 18, 531 (1988)

22) S. N. Thompson \& R. W.-K. Lee: Insect Biochem. 18, 21 (1988)

23) S. N. Thompson, R. W.-K. Lee \& N. E. Beckage: Arch. Insect Biochem. Physiol. 13, 127 (1990)

24) O. Kukal, A. S. Serianni \& J. G. Duman: J. Comp. Physiol. B 158, 175 (1988)

25) M. Takahashi, C. Shudo, K. Matsushita, M. Nishina, E. Hori, K. Kato, M. Takashita \& A. Osaka: Jpn. J. Sanit. Zool. 40, 127 (1989)

26) K. Iida, O. Hidoh, J. Fukami \& K. Kajiwara: Chem. Pharm. Bull. 39, 210 (1991)

27) H. M. Salleh \& J. F. Honek: FEBS Lett. 262, 359 (1990) 
要

約

トレハラーゼ阻害戍バリドキシルアミン $\mathrm{A}$ のヨ トウガ幼虫に及ぼす影響の NMR スペクトルに よる解析

河野義明，竹田 敏，亀田幸彦 高橋正和，松下和弘，仁科正実

堀栄太郎

トレハラーゼ阻害剤バリドキシルアミン A (VAA, 10 $\mu \mathrm{g} /$ insect）をヨトウガ終齢幼虫に注射すると体節筋の 弛緩や背脈管膊動数の減少が起き，1日後の中腸トレハ ラーゼ活性は $90 \%$ 阻害された，処理幼虫はその後蛹化
不全で死亡した。体液主要成分への影響を NMRによ り測定した。 ${ }^{13} \mathrm{C}$ ーグルコースを注射してトレハロース合 成能を調べたところ，VAA には影響されず活発であっ た.VAA 処理 1 日後では, トレハロース濃度のみが上 昇し，他の成分への影響はなかった。トレハロースはそ の後も増加し続けたが，その他の成分は終糩 5 日目には 減少した。前蛹期には，ほとんどの 成分の 濃度が上昇 し，コリンと $N$-アセチルグルコサミンが出現した．前 蛹期には変態に必要な成分が体液中に放出されるが， VAA の影響でエネルギー代謝に異常をきたした各組織 ではそれらを利用できないために，成分の蓄積が起きた と考えられる。 